\title{
Bermain Fantasi: Pengembangan Model Pembelajaran Menulis Fiksi Ilmiah
}

\author{
Al Kayyizu Azizin Nisa' ${ }^{1}$, Roekhan ${ }^{1}$, Wahyu Siswanto ${ }^{1}$ \\ ${ }^{1}$ Pendidikan Bahasa Indonesia-Universitas Negeri Malang
}

\section{INFO ARTIKEL}

\section{Riwayat Artikel:}

Diterima: 30-03-2020

Disetujui: 13-07-2020

\section{Kata kunci:}

fantasy play model; write science fiction; model bermain fantasi, menulis fiksi ilmiah

\begin{abstract}
ABSTRAK
Abstract: This research and development aims to produce a short story learning model of learning with science fiction. Then, test the effectiveness of Fantasy Play model products. The use of the development model used is 4-D which has stages of define, design, develop, and desseminate. The test is carried out with an expert validation process and a small scale field test. The test results indicate that the qualifications are feasible to implement and have a normal distribution> 0.05 and the significance is 0.000 $<0.05$. These results indicate that the Fantasy Play model can be used in learning.
\end{abstract}

\begin{abstract}
Abstrak: Penelitian dan pengembangan ini bertujuan untuk mengahasilkan model pembelajaran menulis cerpen dengan jenis fiksi ilmiah. Kemudian, melakukan pengujian efektivitas produk model Bermain Fantasi. Penggunaan model pengembangan yang digunakan ialah 4-D yang memiliki tahapan define, design, develop, dan desseminate. Pengujian dilakukan dengan proses validasi ahli dan uji lapangan skala kecil. Hasil uji menunjukkan kualifikasi layak diimplementasikan dan berdistribusi normal $>0,05$ serta signifikasi diperoleh $0,000<0,05$. Hasil tersebut menunjukkan bahwa model Bermain Fantasi dapat digunakan dalam pembelajaran.
\end{abstract}

\author{
Alamat Korespondensi: \\ Al Kayyizu Azizin Nisa' \\ Pendidikan Bahasa Indonesia \\ Universitas Negeri Malang \\ Jalan Semarang 5 Malang \\ E-mail: al.azizin12@gmail.com
}

Menulis fiksi merupakan kegiatan produktif yang membutuhkan pengalaman dan pengetahuan. Sayuti dan Esti (2012) mengungkapkan bahwa kegiatan menulis oleh penulis akan menimbulkan identitas diri dalam mengaitkan gagasan, pandangan, dan konteks sosial budaya yang terdapat di sekeliling penulis. Pada dasarnya menulis fiksi dapat dilakukan dengan tahap pramenulis, menulis, dan pascamenulis. Tahap pramenulis berisi kegiatan pengumpulan bahan atau referensi pendukung tulisan seperti memunculkan ide cerita dari kejadian atau cerita di lingkungan sosial penulis. Hal ini dilakukan karena fiksi merupakan skenario yang bercermin dari dunia nyata. Selain itu, bahan tulisan juga dapat diperoleh dari buku, koran, artikel, atau cerita lain yang berpotensi membangun ide cerita. Kemudian, pada tahap menulis dapat dilakukan pengembangan ide cerita sesuai dengan bahan tulisan dan kreativitas pengarang. Tahap terakhir ialah pascamenulis yang digunakan untuk mengecek ulang hasil penulisan dan kelogisan cerita. Kegiatan menulis fiksi ini memerlukan daya imajinasi yang memiliki nilai-nilai. Fiksi ilmiah yang mengaitkan fiksi dengan sains menunjukkan kesesuaian dengan generasi milenial sekarang ini.

Generasi milenial di era revolusi 4.0 tidak hanya menguasai literasi lama yang menunjukkan kegiatan membaca dan menulis saja namun juga perlu menguasai literasi data, teknologi, dan sosial (Fitriani dan Aziz, 2019). Hal ini menunjukkan perlunya pembelajaran fiksi ilmiah pada materi cerpen bagi siswa sebagai generasi milenial untuk berstandar masa depan. Raven (2017166) menyatakan kegunaan fiksi ilmiah sebagai strategi yang menjelaskan dan menggambarkan konsep masa depan yang berbentuk seperti apa dan mengapa alasannya perkembangan tersebut dilakukan. Penelitian Reven membahas mengenai perkembangan energi masa depan yang mengaitkan penggambaran realitas materi dari dunia yang diceritakan saat ini yang akan terjadi di masa depan. Fiksi ilmiah yang dibuat saat ini melalui prosa atau film merupakan representasi pemikiran manusia untuk kemajuan keilmiahan masa depan. Peserta didik sebagai pembangun generasi masa depan perlu memahami dan produktif dari segala bidang salah satunya pembelajaran fiksi ilmiah. Sabani (2018) mengungkapkan permasalahan generasi milenial saat ini yang bersosial dengan menggunakan sosial media yang memiliki kebiasaan buruk dalam melakukan debat kusir virtual yang akan membahas banyak hal dan tidak menyaring jenis kritik, saran, atau pujian secara baik. Penguasaan sosial media dan berinteraksi di dalamnya dengan tidak langsung bertatap muka mengakibatkan menurunnya nilai-nilai kesopanan. Dalam hal ini perlu penanganan pendidikan yang mengaitkan perkembangan sains dan teknologi dengan ilmu seni agar menghasilkan produk maupun pemikiran dari generasi muda yang kreatif.

Pada pendidikan, seni memiliki peran yang selaras dengan tujuan pendidikan. Menurut Triyanto (2014), ranah pendidikan menunjukkan pengembangan terkait sikap ekspresif, apresiasif, dan kreatif memiliki huhubungan yang dapat membentuk kepribadian bagi siswa secara sosial maupun individu. Proses menulis fiksi di sekolah salah satunya ialah 
pembelajaran cerpen dengan jenis fiksi ilmiah. Menurut Nurmina (2014), cerita fiksi ialah salah satu pembelajaran yang efektif dalam mendidik, meningkatkan dan menyalurkan, serta menghibur bagi penulis dan pembaca. Fiksi ilmiah tergolong sebagai fiksi tingkat tinggi yang memerlukan imajinasi dan fantasi secara bersamaan. Karya fiksi ilmiah memiliki kemenarikan dan manfaat dalam mempelajari, membaca, atau menciptakan karya. Ketika seseorang mempelajari, membaca, dan membuat karya fiksi ilmiah, maka juga akan mempelajari unsur pembangun cerita dan ilmu pengetahuan sekaligus. Particularly for young readers, science fiction can capture imaginations and inspire lasting interests in science (Lundquist, 2012). Proses berpikir yang kreatif dan logis akan diperlukan saat menulis fiksi ilmiah. Selain itu, fiksi ilmiah yang menggunakan latar teknologi dan sains yang dikembangkan menggunakan unsur cerita dapat menjadi inspirasi bagi pengembangan teknologi nyata di masa depan. Kasus penciptaan robot dalam fiksi sebelum menjadi bagian dari fiksi ilmiah dipopulerkan Joseph Capek dan Karel Capek tahun 1921 untuk memprotes pertumbuhan pesat teknologi yang berimbas kepada perlawanan robot terhadap manusia menjadi perkembangan prosa fiksi ilmiah sebagai kreasi masa kini (Hockstein, dkk., 2007). Hal ini menjadi contoh perkembangan fiksi pada ranah robotik memicu keilmuan bereksperimen dan dapat dirasakan saat ini dalam bentuk nyata, seperti pesawat tanpa awak kapal (drone), robot medis, peralatan produksi pabrik-pabrik, dan sebagainya. Menulis fiksi akan membantu siswa dalam menciptakan karya baru dan meningkatkan kreativitas, sedangkan menulis fiksi ilmiah akan membantu siswa berpikir kreatif dalam menciptakan hal baru dari sifat fantasi menjadi ilmiah. Konsep ilmiah pada fiksi yang dibuat dapat berupa teori yang ingin digunakan dalam cerita atau membuat konsep ilmu baru yang dikembangkan melalui fantasi siswa. However, science fiction prototypes allow for a focused, tailored and creative way to think about possible futures around a particular issue (Merrie, dkk., 2018). Pendapat tersebut menjelaskan bahwa fiksi ilmiah dapat merubah masa depan melalui kemungkinan-kemungkinan yang kreatif. Hal ini dapat diartikan bahwa menulis fiksi terutama fiksi ilmiah perlu dipelajari oleh siswa sebagai generasi pencipta masa depan.

Proses pembelajaran yang diterapkan guru dari awal hingga akhir kegiatan merupakan model pembelajaran. Menurut Aqib dan Ali (2016), model pembelajaran adalah bentuk pembelajaran yang tergambar dari awal sampai akhir yang disajikan secara khas oleh pendidik di kelas. Setiap model yang diterapkan oleh guru ditujukan untuk memaksimalkan kegiatan belajar siswa. Fokus dari kegiatan pembelajaran tersebut ialah untuk mencapai tujuan yang diinginkan. Model pembelajaran yang digunakan untuk mengaktifkan peserta didik disusun sesuai prinsip dan teori belajar (Rahmah, 2014). Perbedaan tujuan yang ingin dicapai akan membentuk ciri khas pada prosedur kegiatan model pembelajaran. Selain itu, model pembelajaran dapat dikembangkan dengan memasukkan strategi, metode, dan media dengan tujuan membantu kegiatan pembelajaran dalam model tersebut.

Model pembelajaran yang akan dikembangkan pada penelitian ini adalah model Bermain Fantasi. Rencana pembelajaran yang dipilih akan membantu memperjelas dan menuntun pencapaian tujuan yang diinginkan dan sebaliknya (Bahri, 2019). Pengembangan model menjadi salah satu cara mengembangkan rencana pembelajaran yang baik untuk tujuan tertentu. Model pembelajaran yang dapat diterapkan dalam menulis fiksi ilmiah ialah model Bermain Fantasi. Kegiatan bermain dalam kegiatan pembelajaran memiliki pengaruh tertentu. Kurnia (2012) menyatakan bahwa bermain memiliki kelebihan bagi individu dalam berpikir dan berperilaku imajinatif yang berarti berhubungan dengan daya berkhayal untuk kreativitas anak. Bermain dilakukan dengan berbagai jenis kegiatan dan pada model Bermain Fantasi bermain dilakukan dalam kegiatan mengembangkan ide melalui permainan kelompok. Hal ini tentu akan membangkitkan semangat siswa dalam memunculkan ide menulis dan membantu hasil ide yang akan ditulis. Khayalan yang dihasilkan dalam kegiatan bermain akan mendukung proses kreatif siswa saat menulis cerita. Selain itu, bermain dapat digunakan untuk menenangkan kegugupan dan menguatkan persahabatan antar siswa. Kegiatan bermain dapat menjadi alternatif bagi siswa dalam beraktifitas di dalam kelas. Oleh karena itu, metode bermain menjadi salah satu kegiatan pembelajaran yang menyenangkan dan efektif. Model Bermain Fantasi memiliki kegiatan berkhayal yang terarah. Selain itu, terdapat kegiatan bermain yang berujuan untuk membantu siswa menciptakan tokoh dan penokohan dalam cerita dan memotivasi siswa dalam proses pembelajaran.

Fantasi merupakan salah satu kemampuan di dalam otak manusia yang dapat dilakukan secara sadar atau tidak sadar dan menghasilkan khayalan. Kegiatan berfantasi yang dilakukan seseorang tersebut merupakan salah satu kegiatan berpikir asosiatif. Khayalan yang diciptakan bersifat bebas tanpa memiliki batasan dan dapat pula menciptakan bentuk-bentuk yang tidak realistis. Fantasi yang menghasilkan khayalan juga dapat dikategorikan sebagai bentuk kreativitas manusia. Temuantemuan para ahli juga diperoleh dari proses berkhayal yang diwujudkan menjadi asumsi-asumsi temuan, misalnya Newton yang menemukan teori daya tarik bumi karena mengkhayalkan sebab dari kejadian jatuhnya buah apel yang menimpa kepalanya. Menurut Aripin dan Purwasih (2017), bila dilihat pada sudut proses klasifikasi bidang sains, matematika juga banyak melakukan proses kreatif pemikiran daripada menghapal saja. Dalam hal ini berkaitan dengan kemampuan berpikir rasional dan irasional dalam menciptakan sebuah karya.

Kegiatan berfantasi dapat diperoleh dari objek nyata sebagai rangsang otak dalam menciptakan bentuk baru sesuai pengetahuan yang dimiliki. Fantasi bersumber dari kemampuan kognitif yang dimiliki anak. Fantasi tersebut berkaitan dengan kegiatan khayalan terhadap objek atau peristiwa tertentu. Suryadi (2010) menyatakan bahwa fantasi dapat berupa peristiwa atau kejadian masa lampau dan sesuatu yang akan terjadi kelak atau berpusat di masa yang akan datang. Fantasi terjadi ketika wujud 
nyata sebuah objek atau peristiwa tidak dapat mewakili pemikiran seseorang. Fantasi seringkali digunakan saat sesorang menghadapi masalah di dunia nyata seperti solusi dengan bentuk khayalan sesuai keinginan. Hal ini menunjukkan bahwa fantasi menjadi jalan keluar atau pelarian manusia sebab subjek atau objek dalam bentuk nyata tidak dapat memenuhi keinginan. Fantasi juga dibentuk dari kemampuan berpikir manusia sebagai makhluk berakal.

\section{METODE}

Model pengembangan yang digunakan pada penelitian ini ialah pengembangan 4-D oleh Thiagarajan, dkk dengan empat tahapan, yakni penetapan (define), desain (design), pengembangan (develop), dan penyebaran (dissemination). Model pengembangan tersebut digunakan karena memiliki proses yang mendukung penelitian menulis fiksi ilmiah menggunakan model Bermain Fantasi. Tahap penetapan berisi kegiatan merumuskan dan mendefinisikan kebutuhan dalam kegiatan pembelajaran. Tahap perencanaan bertujuan untuk mengumpulkan bahan pembelajaran yang dibutuhkan. Tahap pengembangan berguna untuk merancang komponen model pembelajaran yang dibuat. Tahap penyebaran bertujuan untuk mempublikasikan hasil model pembelajaran. Penelitian ini juga menggunakan desain penelitian kuasi eksperimen dengan kegiatan pretest dan posttest pada kelompok eksperimen dan kontrol untuk menguji coba keefektifan produk.

Uji coba produk bertujuan untuk mengetahui kelayakan produk yang dikembangkan. Pengembangan model dilakukan uji validasi kepada validator ahli model pembelajaran, ahli pembelajaran sastra, dan praktisi serta terdapat uji lapangan. Ahli model pembelajaran adalah ahli yang memiliki pengetahuan dan wawasan pada bidang model pembelajaran. Ahli pembelajaran sastra adalah ahli yang memiliki pengetahuan dan wawasan pada bidang sastra terutama pada teori dan penerapan pembelajaran sastra. Ahli praktisi adalah guru yang mengajar mata pelajaran Bahasa Indonesia dan telah memiliki pengalaman lama pada bidang pembelajaran. Uji lapangan dilakukan kepada siswa SMA PGRI 2 Jombang sebagai pelaksana model pembelajaran.

Analisis data dilakukan terhadap data verbal dan angka. Data verbal diperoleh dari saran dan komentar ahli model pembelajaran, pembelajaran sastra, dan praktisi. Kemudian, data angka merupakan hasil perolehan penilaian produk pada angket yang dihitung dalam bentuk persentase. Selanjutnya, pengujian efektivitas diperoleh dari skor menulis fiksi ilmiah oleh siswa pada uji lapangan. Uji efektivitas dilakukan untuk mencari daya beda dari penggunaan model Bermain Fantasi.

\section{HASIL}

Hasil penelitian pengembangan ini menunjukkan tiga aspek pemahasan, yakni (1) deskripsi model, (2) hasil kelayakan model, dan (3) hasil menulis siswa. Ketiga aspek tersebut dipaparkan sebagai berikut.

Deskripsi model berisi pemaparan isi model Bermain Fantasi yang dibentuk dalam wujud buku. Pertama, pendahuluan berisi konteks dan landasan dari model Bermain Fantasi, yaitu fiksi ilmiah, tujuan, dan landasan teori. Kedua, isi dari model Bermain Fantasi, yakni pengertian, karakteristik, sistem sosial, prinsip reaksi, sistem pendukung, dan sintak model. Ketiga, perencanaan dan implementasi model Bermain Fantasi yang berisi Rencana Pelaksanaan Pembelajaran (RPP) dan skenario pelaksanaan Bermain Fantasi dalam pembelajaran.

Model Bermain Fantasi dilakukan dua kali uji kelayakan. Kelayakan konsep dasar model Bermain Fantasi memperoleh $78,57 \%$ dari ahli pembelajaran sastra dan 70,83\% dari ahli model pembelajaran. Rata-rata yang diperoleh dari hasil pengujian sebesar 74,7\% yang menunjukkan kualifikasi cukup layak dan perlu adanya revisi dari catatan ahli. Kemudian, produk direvisi dan dilakukan uji kelayakan konsep dasar model Bermain Fantasi yang kedua. Hasil uji validasi kedua menunjukkan skor 92,85\% dari ahli pembelajaran sastra, 95,83\% dari ahli model pembelajaran, dan ahli praktisi sebesar 95\%. Nilai rata-rata yang diperoleh sebesar 94,56\% yang menunjukkan kualifikasi sangat layak dan dapat diimplementasikan di lapangan.

Aspek penilaian kedua ialah uji kelayakan relevansi model Bermain Fantasi dengan kurikulum. Uji validasi pertama oleh ahli pembelajaran sastra sebesar $75 \%$ dan ahli model pembelajaran sebesar $75 \%$. Nilai rata-rata menunjukkan $75 \%$ dengan hasil kualifikasi layak. Uji kelayakan kedua diperoleh hasil 91,66\% oleh ahli pembelajaran sastra, ahli model pembelajaran sebesar $75 \%$, dan ahli praktisi sebesar $100 \%$. Nilai rata-rata yang diperoleh sebesar 88,88\% dengan kualifikasi sangat layak dan dapat diimplementasikan.

Aspek penilaian ketiga yakni uji kelayakan relevansi model Bermain Fantasi pada pelaksanaan pembelajaran menulis fiksi. Penilian dari ahli pembelajaran sastra sebesar $95 \%$ dan ahli model pembelajaran sebesar $75 \%$. Hasil validasi pertama ini memperoleh hasil rata-rata $85 \%$ yang menunjukkan sangat layak. Hasil validasi pertama dilakukan revisi karena masih memiliki banyak catatan dari ahli. Kemudian, pengujian kelayakan kedua menunjukkan hasil 91,66\% dari ahli pembelajaran sastra, 95,83\% dari ahli model pembelajaran, dan 95,83\% dari ahli praktisi. Nilai rata-rata menunjukkan $94,44 \%$ dengan kualifikasi sangat layak dan dapat diimplementasikan.

Aspek penilaian keempat ialah uji kelayakan penyajian buku model Bermain Fantasi. Hasil penilaian menunjukkan 90\% dari ahli pembelajaran sastra dan $90 \%$ dari ahli model pembelajaran. Rata-rata nilai menunjukkan skor $90 \%$ dengan kualifikasi sangat layak dan dapat diimplementasikan. Hasil uji validasi pertama memiliki catatan ahli untuk direvisi sebelum diterapkan. Kemudian, uji validasi kedua diperoleh hasil 95\% oleh ahli pembelajaran sastra, 100\% oleh ahli model pembelajaran, dan $90 \%$ dari ahli praktisi. Nilai rata-rata yang diperoleh pada validasi kedua ini ialah $95 \%$ dengan kualifikasi 
sangat layak dan daat diimplementasikan di kelas. Uji efektivitas dilakukan dengan menggunakan kelas eksperimen dan kelas kontrol. Pengujian model pada kelas uji dilakukan untuk menguji hipotesis (ha) komparatif yakni terdapat perbedaan hasil menulis fiksi ilmiah yang positif fn signifika pada kelompok kontrol da eksperimen. Hipotesis dapat dijelaskan dengan rumus statistik, yaitu Ha: $1 \neq 2$. Pengujian dilakukan dengan uji normalitas, uji homogenitas, da uji t. Hasil uji normalitas yang digunakan dengan teknik Shapiro-Wilk. Hasil uji normalitas pada posttest kelas eksperimen menunjukkan signifikasi 0,227. Kemudian, posttest kelas kontrol menujukkan hasil 0,088. Hasil perolehan kedua kelas tersebut ditunjukkan pada tabel 1.

\section{Tabel 1. Hasil Uji Normalitas}

\begin{tabular}{|c|c|c|c|c|c|c|c|}
\hline & \multirow[t]{2}{*}{ Kelas } & \multicolumn{3}{|c|}{ Kolmogorov-Smirnov(a) } & \multicolumn{3}{|c|}{ Shapiro-Wilk } \\
\hline & & Statistic & Df & Sig. & Statistic & Df & Sig. \\
\hline \multirow[t]{4}{*}{ Hasil Menulis Siswa } & Pretest Kelas Eksperimen (Bermain Fantasi) &, 116 & 34 & $200(*)$ & ,960 & 34 & 247 \\
\hline & Post Test Kelas Eksperimen (Bermain Fantasi) & 106 & 34 & $200(*)$ & 959 & 34 & 227 \\
\hline & Pretest Kelas Kontrol (Sinektik) & 134 & 34 & 126 & 960 & 34 & 251 \\
\hline & Post Test Kelas Kontrol (Sinektik) & 168 & 34 & 016 & 945 & 34 & 088 \\
\hline
\end{tabular}

Hasil uji homogenitas dilakukan untuk mengetahui data dari dua distribusi atau lebih memimiliki variasi yang sama atau tidak. Pada hasil data menulis fiksi ilmiah siswa kelas eksperimen dan kontrol menunjukkan signifikasi sebesar 0,587. Hasil uji homogenitas pada tabel 2.

Tabel 2. Hasil Uji Homogenitas

\begin{tabular}{llrrrrr}
\hline & & Levene & & & \\
& & Statistic & df1 & df2 & Sig. \\
\hline Hasil & Based on Mean &, 298 & 1 & 66 &, 587 \\
Menulis & Based on Median &, 100 & 1 & 66 &, 752 \\
Siswa & Based on Median and with adjusted df &, 100 & 1 & 64,439 &, 752 \\
& &, 337 & 1 & 66 &, 563 \\
\hline
\end{tabular}

Setelah uji normalitas dan homogenitas selesai dilakukan, selanjutnya penghitungan uji t. Uji t sampel independen digunakan untuk mengetahui perbedaan rata-rata pada dua sampel yang berpasangan. Penggunaan uji statistik parametrik ditunjukkan pada baris equal variances assumed. Nilai t (beda) menunjukkan nilai positif sebesar 7,241 dengan nilai signifikasi (2-tailed) 0,000. Berikut hasil uji t yang ditunjukkan pada tabel 3.

Tabel 3. Hasil Uji t Sampel Independen

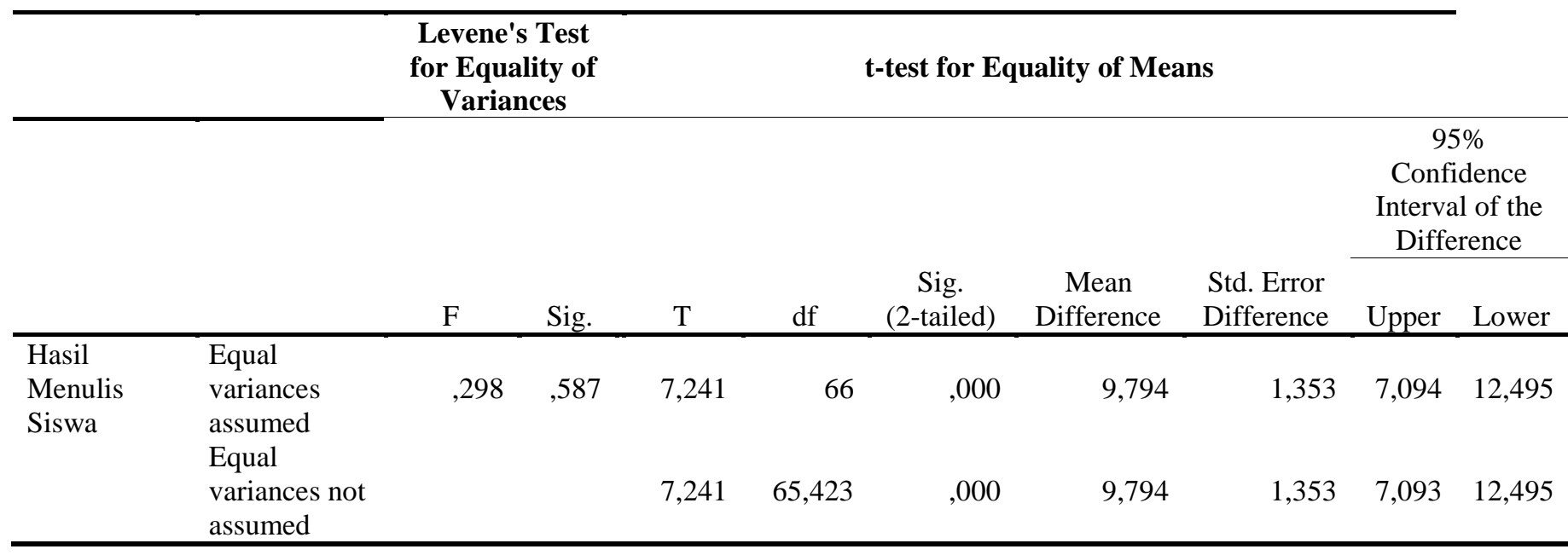




\section{PEMBAHASAN}

Penelitian pengembangan ini menghasilkan model pembelajaran untuk menulis fiksi ilmih yakni model Bermain Fantasi. Fiksi ilmiah ialah jenis fiksi yang menggunakan unsur ilmu pengetahuan dan khayalan sebagai ide cerita. Fiksi ilmiah berada di luar realita dan dapat digunakan sebagai lensa untuk melihat aktivitas dasar dari praktik keilmuan (Kaye \& D., 2014). Selain itu, fiksi ilmiah dipaparkan dengan pembahasan mengenai konsep fiksi ilmiah yang relevan dengan kemajuan era digital saat ini. Siswa di Indonesia perlu dikuatkan pada pemikiran yang mengintegrasi informasi, membuat simpulan, dan generalisir pengetahuan pada bidang-bidang lain. Hal ini menunjukkan bahwa pembelajaran sastra juga berperan dalam banyak ilmu, salah satunya fiksi ilmiah. Ciri fiksi ilmiah yang memaparkan sundut pandang masa depan dengan kemajuan hasil imajinasi memiliki motivasi bagi perkembangan dunia. Hal ini dapat digunakan sebagai tujuan pembelajaran fiksi ilmiah. Kemudian, hasil penelitian oleh Ayuni, dkk. (2013) menunjukkan pengaruh sebuah storytelling terhadap perilaku empati anak terutama pada daya fantasi. Hal ini berarti fiksi mampu memberikan pengaruh bagi emosional anak dan melatih fantasi.

Model Bermain Fantasi memiliki definisi sebagai rancangan pembelajaran yang digunakan untuk merangsang daya khayal dengan kegiatan menyenangkan untuk mengembangkan kreativitas dan produktivitas. Tujuan model dibuat sesuai kegiatan dan dapat diukur sesuai pembelajaran. Rosa (2015) menyatakan bahwa upaya dalam mengetahui tujuan ialah penilaian terhadap hasil akhir pembelajaran. Tujuan model Bermain Fantasi tersebut ialah menciptakan pembelajaran yang dapat membantu siswa menghasilkan ide dari kegiatan berkhayalan dan mengembangkannya dalam membuat cerita. Landasan teori model menunjukkan konsep bermain dan berkhayal yang digunakan dalam kegiatan model Bermain Fantasi. Konsep pertama ialah bermain yang merupakan kegiatan aktif menyenangkan. Menurut Abdullah, dkk. (2008:4), bermain dapat menunjukkan diri anak sebagai seorang yang belajar karena berkaitan dengan linkungan dan hubungan sosial, mengaktifkan intelektual, melatih emosi, dan meningkatkan cara kerja penyelesaian masalah. Bermain membutuhkan fisik dan mental yang aktif agar anak terlatih dalam mengaplikasikannya pada banyak bidang, seperti pembelajaran di dalam atau luar kelas. Sembilan manfaat yang dapat digunakan sebagai kegiatan pembelajaran, yaitu (1) melatih kemampuan motorik, (2) melatih konsentrasi, (3) kemampuan sosialisasi meningkat (termasuk berkompetisi), (4) melatih keterampilan berbahasa, (5) menambah wawasan, (6) mengembangkan kemampuan untuk problem solving, (7) mengembangkan jiwa kepemimpinan, (8) mengembangkan pengetahuan tentang norma dan nilai, dan (9) meningkatkan rasa percaya diri. Oleh karena itu, kegiatan bermain dapat menimbulkan motivasi bagi siswa dalam pembelajaran. Landasan Bermain Fantasi yang kedua ialah fantasi yakni salah satu kemampuan atau daya dalam otak manusia yang dapat dilakukan secara sadar atau tidak sadar dan menghasilkan khayalan. Konsep berkhayal menggunakan kemampuan kognitif. Kemampuan kognitif juga dipelajari dalam ilmu psikologi, salah satunya teori beban kognitif yang mengaitkan cara berpikir manusia terhadap semua bidang ilmu sains dan sosial (Leppink, 2017:386). Kinerja manusia dalam berpikir menjadikan adanya beban kognitif yang muncul sebagai konsep daya khayal yang produktif. Teori tersebut digunakan pada banyak bidang sebagai pedoman dalam berpikir logis kreatif.

Model Bermain Fantasi memiliki karakter sebagai ciri sebuah model pembelajaran. Karakteristik Bermain Fantasi, yakni membangkitkan daya pikir berimajinasi dan berkhayal, menguatkan pemahaman siswa lewat contoh langsung, menghasilkan ide mandiri melalui media video culikan film dengan khayalan, menghasilkan ide khayalan yang bervariasi, sertamembantu menciptakan ide unsur tokoh dan penokohan melalui kegiatan bermain. Kemudian, komponen model yang menunjukkan tiga aspek, yaitu sistem sosial, prinsip reaksi, dan sistem pendukung. Sistem sosial menunjukkan interaksi antara guru dengan siswa dan siswa dengan siswa lain dalam penggunaan model. Pembelajaran merujuk pada kegiatan siswa aktif maka guru juga perlu meningkatkan kualitas kognitif dan keterampilannya untuk menaungi kreatifitas siswa. Perkembangan zaman tidak dapat dibendung oleh siapa saja yang membuat Sumber Daya Manusia dalam mewadahi untuk siap menyesuaikan serta mampu bersaing pada skala global terutama kualitas tenaga pendidik. Prinsip reaksi merupakan reaksi yang dilakukan guru sebagai pemandu dan fasilitator bagi siswa dalam pembelajaran. Selanjutnya, sistem pendukung berisi pengelolaan kelas, media, dan alat yang digunakan sebagai pendukung pelaksanaan model Bermain Fantasi. Sistem pendukung berisi pengondisian kelas dan media dalam mendukung pelaksanaan model Bermain Fantasi. Penggunaan alat bantu atau media dengan benar maka akan membantu memotivasi kegiatan belajar dan dapat meningkatkan prestasi peserta didik. Media yang digunakan model Bermain Fantasi yakni, rangkaian suara alam, efek suara, video cuplikan film fiksi ilmiah, narasi, dan permainan campur ide.

Sintak berisi tahapan kegiatan model Bermain Fantasi yang berisi lima tahap, menstimulus, menemukan ide, mengembangkan ide, menulis cerita, dan merevisi cerita. Pertama, tahap menstimulus berisi kegiatan stimulasi imajinasi dan stimulasi fantasi yang digunakan dalam merangsang khayalan siswa dengan relaksasi suara alam dan meyelesaikan masalah dari hasil imajinasi. Kedua, tahap menemukan ide berisi langkah ide stimulus dan ide baru dengan kegiatan pemberian bimbingan berkhayal oleh guru yang kemudian dirangsang dengan video cuplikan film untuk menghasilkan ide baru oleh siswa. Ketiga, tahap mengembangkan ide berisi langkah bermain campur ide dan menyusun ide. Kegiatan bermain campur ide dilakukan untuk menghasilkan ide tokoh dan penokohan yang membantu siswa dalam menulis cerita. Kegiatan menyusun ide dilakukan dengan merangkai kerangka dari semua ide yang dikumpulkan sebelum menulis cerita. Keempat, tahap menulis cerita ialah kegiatan menulis cerita menggunakan ide-ide yang telah diperoleh. Proses menulis dilakukan siswa dengan mengembangkan ide menjadi tema, mengembangkan latar, menggambarkan tokoh dan penokohan dari hasil bermain campur ide, membua 
konflik cerita, meningkatkan konflik menjadi klimaks cerita, dan membuat antiklimaks yang menunjukkan amanat dari peristiwa dalam cerita. Kelima, merevisi cerita dilakukan dengan pemberian panduan oleh guru yang kemudian dilanjutan siswa dengan mengoreksi dan membenahi cerita secara mandiri.

Ketiga, perencanaan dan pelaksanaan model Bermain Fantasi. Perencanaan model dibuat dalam bentuk Rencana Pelaksanaan Pembelajaran (RPP). Kemudian, pada pelaksanaan berisi skenario penggunaan model Bermain Fantasi yang dapat dilakukan siswa. Dalam pelaksanaan berisi tahap sesuai sintaks, penjelasan sesuai prosedur, dan instruksi yang dapat dilakukan dalam menggunakan model Bermain Fantasi. Model Bermain Fantasi yang telah dikembangkan memiliki perubahan dari hasil validasi ahli. Revisi diperoleh dari hasil pengujian empat aspek, yaitu kelayakan konsep dasar model Bermain Fantasi, kelayakan relevansi model Bermain Fantasi dengan kurikulum, kelayakan relevansi model Bermain Fantasi pada pelaksanaan pembelajaran menulis fiksi, dan kelayakan penyajian buku model Bermain Fantasi.

Hasil kelayakan konsep dasar model Bermain Fantasi menunjukkan perlunya penguatan sistem sosial dengan sintak model Bermain Fantasi yang berasal dari saran ahli pembelajaran sastra. Kemudian, saran ahli model pembelajaran ialah perlunya pendefinisian yang jelas terhadap istilah bermain fantasi, tujuan dalam model perlu mencerminkan tindakan dan tujuan dari proses pembelajaran, penggunaan media perlu dipilih dengan ciri pengetahuan atau sains, sistem sosial yang menunjukkan peran guru dan siswa perlu diperkuat, prinsip reaksi dari aspek sains perlu diperjelas, dan perumusan alternatif untuk sistem pendukung model. Saran pada kelayakan konsep dasar yang pertama ditindaklanjuti dengan melakukan revisi terhadap konsep model Bermain Fantasi yang diperjelas dengan memperkuat bentuk rangsangan dan khayalan yang dilakukan dalam memperoleh ide cerita serta mengembangkannya dengan kegiatan bermain. Menurut Holis (2006), kegiatan bermain dapat mengoptimalkan kemampuan dan potensi pada anak. Hal ini dipercayai karena anak sebenarnya memiliki kemampuan tinggi yang berbeda-beda sesuai bidang. Bermain menjadi salah satu alternatif siswa meningkatkan kemampuan kognitif yang kratif. Selanjutnya, tujuan model diperbaiki dengan merumuskan pencapaian kegiatan dalam pelaksanaan pembelajaran. Tujuan tercapai dapat diketahui dengan penilaian (Rosa, 2015). Sistem sosial dalam model diperkuat dengan menunjukkan interaksi antara siswa dengan guru dan siswa dengan siswa lain dalam menerapkan model. Menurut Inah (2015), salah satu komunikasi yang dapat dilakukan pada pembelajaran ialah komunikasi banyak arah yang mengaitkan guru dengan siswa dan antar siswa dalam proses interaksi. Selanjutnya, prinsip reaksi ditunjukkan melalui kegiatan siswa dengan ilmu pengetahuan yang menjadi referensi menulis ide dan cerita. Unsur ilmiah pada model salah satunya dengan menggunakan narasi dengan penjelasan proses gelombang suara secara sains untuk diperdengarkan kepada siswa pada kegiatan rangsang suara. Hasil revisi dilakukan validasi kedua dan memperoleh kualifikasi "sangat layak" dan dapat diimplementasikan dalam kelas.

Hasil kelayakan relevansi model Bermain Fantasi dengan kurikulum berkaitan dengan Kompetensi Inti (KI), Kompetensi Dasar (KD), dan indikator. Hasil validasi tidak menunjukkan saran dari ahli namun mengalami kenaikan nilai persentase. Validasi pertama menunjukkan kualifikasi "layak". Kemudian, validasi kedua memperoleh kualifikasi "sangat layak". Hasil kelayakan relevansi model Bermain Fantasi pada pelaksanaan pembelajaran menulis fiksi memiliki saran dari validator. Saran ahli model pembelajaran ialah perlunya konsep fantastis saintis pada kegiatan model, penekanan aspek sains yang jelas, dan unsur sains dalam model perlu dianalisis lebih mendalam, difantasikan, serta diintegrasikan dalam kegiatan penulisan cerita. hasil saran dilakukan revisi, yakni penguatan pada kegiatan tahap berkhayal dengan penambahan narasi berisi unsur sains. Penguatan tersebut dilakukan dengan pemberian narasi yang memiliki penjelasan mengenai gelombang suara yang dilakukan pada tahap menstimulus khayalan. Proses imajinasi pada tahap ini penting karena daya berpikir khayalan yang akan meningkatkan kreativitas bagi siswa. Konsep imajinasi merupakan awal dari realita, bukan seperti yang dipahami orang saat ini bahwa imajinasi turunan dari realita. Oleh karena itu, daya khayal akan membantu siswa menghasilkan fiksi ilmiah dengan ide yang orisinal. Kemudian, mengembangkan ide dilakukan dengan kegiatan bermain campur ide yang menghasilkan ide tokoh dan penokohan untuk digunakan dalam tahap menulis cerita. Aktifitas bermain dalam pembelajaran memiliki dampak positif bagi siswa, terutama memberikan rasa senang dan dan dapat dinikmati secara bersama-sama. Kesan menyenangkan dari sebuah permainan akan berdampak pada respon dan tindakan pada sebuah kegiatan yang produktif. Selain memberi rasa senang, bermain campur ide juga dapat membantu siswa dalam menulis dan melatih interaksi sosial antar siswa dengan hasil ide yang tidak terduga.

Hasil revisi validasi pertama menghasilkan model Bermain Fantasi yang kemudian dilakukan validasi kedua. Kualifikasi yang diperoleh pada validasi kedua ialah "sangat layak", namun tetap memiliki saran yang perlu diperbaiki. Saran berasal dari ahli pembelajaran sastra yang menyebutkan bahwa model Bermain Fantasi perlu memastikan menjadi model yang akan membantu siswa dalam kegiatan pembelajaran. Saran tersebut digunakan untuk merevisi langkah-langkah dan media yang dapat membantu siswa menghasilkan tulisan yang sesuai dengan tujuan. Dalam hal ini, penggunaankegiatan bermain yang secara langsung untuk membantu siswa menemukan ide penciptaan tokoh dan penokohan cerita yakni campur ide. Kurnia (2012) menyatakan bahwa bermain memiliki kegunaan untuk menjelajahi dunia menurut imajinasi anak, dapat mengembangkan kompetensi diri, dan melatih kreativitas anak. Hasil bermain campur ide bersifat kejutan bagi perolehan masing-masing siswa dalam menentukan jenis kelamin, fisik, dan watak. Ide yang telah dimiliki siswa dapat dikembangkan sesuai ide latar yang diperoleh. 
Kelayakan penyajian buku model Bermain Fantasi memeroleh penilaian yang baik, namun perlu adanya perbaikan. Saran dari ahli pembelajaran sastra mengenai isi model yang belum menunjukkan panduan bagi siswa yang kurang komunikatif daripada panduan kepada guru. Saran tersebut dibenahi dengan membuat instruksi dan contoh hasil kegiatan dalam pelaksanaan model. Implementasi tersebut juga dilengkapi dengan Rencana Pelaksanaan Pembelajaran (RPP) bagi guru agar mempermudah dalam menggunakan model Bermain Fantasi. Selanjutnya, ahli model pembelajaran memberi saran mengenai penggunaan gambar pada sampul yang kurang relevansi dengan perspektif pendidikan, kurangnya konsistensi dalam menggunakan gambar ilustrasi dalam buku model, media yang digunakan kurang memunculkan unsur ilmu pengetahuan dan perlu disesuaikan dengan tema fiksi ilmiah, dan struktur buku perlu diurutkan dengan jelas. Revisi dilakukan dengan mengubah gambar sampul menjadi bentuk objek yang lebih netral namun memiliki unsur fantasi. Kemudian, gambar ilustrasi diubah menjadi gambar siswa yang realistis pada seluruh sintak. Media yang digunakan ditambahkan dengan unsur ilmiah melalui kegiatan menganalisis sains dalam video cuplikan film fiksi ilmiah. Selain itu, media suara alam yang digunakan pada tahap menstimulus untuk memfokuskan daya khayal siswa. Media audio baik bagi kemampuan mengarang narasi sebab musik dapat merangsang pikiran dan meningkatkan konsentrasi ingatan, kecerdasan emosional, dan menguatkan kemampuan otak kanan dan kiri secara seimbang. Selanjutnya, bentuk isi buku dibuat lebih terstruktur dengan tiga bab yang disarankan ahli model pembelajaran.

Hasil revisi pertama menhasilkan produk model Bermain Fantasi untuk dilakukan validasi kedua. Hasil validasi kedua menunjukkan peningkatan nilai persentase yang tergolong pada kualifikasi "sangat layak". Saran yang diperoleh pada validasi kedua mengenai penggunaan skor pada rubrik penilaian menulis cerpen yaitu untuk menggunakan nilai bulat. Lalu, saran ahli praktisi mengenai kegiatan dalam RPP perlu ditambah karena fiksi ilmiah merupakan jenis fiksi baru bagi siswa. Oleh karena itu, pengubahan bentuk skor penilaian dan jumlah kegiatan ditambah dalam RPP. Pembenahan dilakukan yang kemudian dilanjutkan kegiatan implementasi dalam kelas sebagai uji lapangan skala kecil.

Hasil uji efektivitas menunjukkan nilai positif pada uji normalitas, homogenitas, dan uji t independen. Hasil uji normalitas menunjukkan signifikasi kelas eksperimen sebesar 0,227 dan kelas kontrol sebesar 0,088. Hal ini berarti perolehan nilai signifikasi > 0,05 yang berarti data penelitian berdistribusi normal. Selanjutnya, uji homogenitas menghasilkan signifikasi nilai sebesar 0,587 yang berarti > 0,05. Hasil tersebut dapat disimpulkan data penelitian memiliki variasi yang sama dan dinyatakan homogen. Setelah uji normalitas dan homogenitas dilakukan, selanjutnya uji beda atau uji t sampel independen dilakukan. Uji t bertujuan untuk mengetahui perbedaan nilai rata-rata dari dua kelompok sampel yang berhubungan atau tidak berhubungan. Dasar penentuan keputusan ialah jika nilai Sig. (2-taled) < 0,05; maka terdapat pebedaan signifikan dari hasil data kelompok eksperimen dengan kontrol. Hasil uji t menunjukkan nilai t (beda) sebesar 7,241 (positif) dan nilai signifikansi (2taled) sebesar 0,000. Nilai positif dari hasil uji t menunjukkan mean kelas eksperimen lebih besar dari kelas kontrol. Jadi, dapat disimpulkan bahwa hipotesis (ha) yakni hasil menulis fiksi ilmiah antara kelas eksperimen dengan kelas kontrol memiliki perbedaan yang signifikan dan diterima.

Hasil tulisan siswa memiliki perbedaan dari hasil pretest dengan posttest. Pada kelas kontrol dari segi judul tidak mengalami perubahan, penggambaran latar dan tokoh juga kurang jelas tanpa menjelaskan penokohan dan hanya terdapat penyebutan nama tokoh utama. Kelas kontrol menunjukkan tidak adanya peningkatan pada hasil konflik, klimaks, dan antiklimaks. Permasalahan dimunculkan dengan adanya pertentangan antara tokoh utama dan lingkungan masyarakat. Pada klimaks masalah berputar mengenai ambisi tokoh utama dalam menyelesaikan penemuan dan dibuat dengan penyingkatan waktu. Pada bagian antiklimaks, hasil pretest dan posttest menunjukkan hasil yang sama persis yakni tokoh utama yang menjadi terkenal dengan temuannya. Rata-rata tema yang digunakan oleh siswa berkaitan dengan kecerdasan buatan, seperti robot canggih. Kornienko, dkk. (2015) menyatakan bahwa kecerdasan buatan ditekankan pada "buatan" yang berisis sistem untuk membentuk simulasi dengan tujuan memberi solusi terhadap masalah hidup manusia atau memiliki arti perangkat dengan fungsi berdasarkan prinsip mesin pintar atau cerdas. Perwujudan inovasi masa depan bagi siswa kelas XI saat ini mengarah pada kecanggihan sebuah alat yang menyerupai kepandaian manusia.

Hasil kelas eksperimen pada kegiatan pretest dan posttest mengalami peningkatan. Pada hasil pretest, judul tidak dibuat, sedangkan hasil posttest judul dibuat dengan penggambaran objek cerita beserta sifatnya. Kemudian, tokoh dan penokohan pada hasil pretest dibuat dengan penyebutan "aku" namun tidak memiliki penggambaran sifat dan fisik tokoh. Hasil posttets menunjukkan perubahan dengan penceritaan tokoh utama yang digambarkan ciri fisik dan sifat dengan teknik analitik dan dramatik. Konflik cerita hasil pretest tidak digambarkan dengan jelas melainkan adanya permasalahan kejahatan di kota yang ditinggali tokoh utama. Hasil posttest menunjukkan gambaran permasalahan dari objek cerita yang memiliki keajaiban untuk membawa tokoh utama ke dimensi lain untuk memulai petualangan. Klimaks hasil pretest tidak menggambarkan kejadian yang jelas karena konflik, klimaks, dan antiklimaks dibuat secara ringkas. Klimaks hasi posttest menunjukkan pertempuran antara tokoh utama yang berada di kelompok protagonis dengan kelompok antagonis yang dilengkapi penggambaran wujud fisik kelompok antagonis. Antiklimaks hasil posttest dibuat dengan happy ending kemenangan dari kubu protagonis dan kembalinya tokoh utama pada kehidupan yang normal, sedangkan hasil pretest tidak digambarkan dengan penjelasan atau penggantungan cerita. 


\section{SIMPULAN}

Model Bermain Fantasi merupakan model yang dapat membantu proses menulis fiksi ilmiah dalam pembelajaran di kelas. Hal ini karena Bermain Fantasi dirancang untuk melatih siswa dalam berpikir fantasi secara bertahap dari imajinasi hingga mampu membenahi ulang hasil karya tulis. Model Bermain Fantasi memiliki tahapan yang lengkap untuk memfasilitasi kegiatan menulis fiksi ilmiah dengan kegiatan menyenangkan dan produktif secara kelompok dan mandiri. Sintak model Bermain Fantasi terdiri dari lima tahapan, yaitu tahap menstimulus, menemukan ide, mengembangkan ide, menulis cerita, dan merevisi cerita. Menulis fiksi ilmiah dengan menggunakan model Bermain Fantasi merupakan proses dalam mefokuskan pembelajaran, berkhayal, memunculkan ide, dan menulis cerita serta merevisi hasil tulisan sehingga hasil yang diperoleh maksimal. Bermain Fantasi dilandasi dengan teori bermain dan fantasi sesuai dengan kegiatan dalam pembelajaran yang dapat disesuaikan dengan lingkungan dan kemampuan siswa. Tujuan Bermain Fantasi sebagai model pembelajaran ialah menghasilkan karya tulis fiksi ilmiah dengan kegiatan yang inovatif. Pengembangan ini masih terbatas dilakukan di kelas karena menggunakan alat-alat elektronik, seperti LCD, laptop, dan pengeras suara untuk menciptakan suasana yang diinginkan pengajar. Interaksi yang diciptakan dengan menggunakan model Bermain Fantasi ialah guru dengan siswa sebagai pemandu alur kegiatan dan fasilitator. Kemudian, interaksi siswa dengan siswa lain tercipta dalam kegiatan bermain campur ide. Selain itu, konsep fiksi dan sains teknologi sebagai objek yang dikerjakan oleh siswa dengan guru dalam bentuk ilmu pengetahuan nyata atau khayalan yang dihadirkan siswa membentuk prinsip reaksi model.

Model Bermain Fantasi juga dilakukan uji kelayakan. Hasil uji kelayakan menunjukkan kelayakan konsep dasar model Bermain Fantasi sebesar 94,56\%. Hasil kelayakan relevansi model Bermain dengan kurikulum sebesar 88,88\%. Hasil kelayakan akurasi model Bermain Fantasi dalam pembelajaran fiksi 94,44\%. Hasil kelayakan penyajian buku model Bermain Fantasi sebesar 95\%. Perolehan rata-rata uji kelayakan menunjukkan kualifikasi "sangat layak". Jadi, model Bermain Fantasi dalam menulis fiksi ilmiah diketahui sangat layak dan dapat diimplementasikan dalam pembelajaran.

Setelah uji kelayakan, model Bermain Fantasi dilakukan uji efektivitas. Uji efektivitas model dilakukan untuk memperoleh hasil efektif atau tidak efektif model Bermain Fantasi yang diimplementasikan dalam pembelajaran. Penelitian ini menggunakan pengujian dengan desain kuasi eksperimen untuk membandingkan bentuk statistik. Pengujian dilakukan pada dua kelompok uji, yaitu eksperimen dan kontrol. Pengujian dilakukan dengan dua tahap, yaitu pretest dan posttest. Setelah kelompok ekperimen dan kontrol melakukan tahap pretest, kemudian dilakukan dengan penerapan model Bermain Fantasi pada kelas eksperimen dan model sinektik pada kelas kontrol. Selanjutnya, dilakukan penghitungan dengan program SPSS uji $\mathrm{t}$ independen yang menunjukkan perbedaan signifikan antara kelas eksperimen dan kontrol. Uji efektivitas memperoleh nilai beda (t) dengan hasil sebesar 7,241 (positif) yang nilai Sig. (2-tailed) sebesar 0,000 ( $<<0,05)$. Hasil menulis siswa kelas eksperimen dinyatakan lebih baik dari kelas kontrol. Jadi, pembelajaran menulis fiksi ilmiah dengan menggunakan model Bermain Fantasi efektif untuk diterapkan.

Hasil menulis fiksi ilmiah oleh siswa menunjukkan perbedaan pada kelas eksperimen dengan kelas kontrol. Perbedaan tersebut pada hasil judul, tokoh/penokohan, konflik, klimaks, dan antiklimaks cerita. Kelas eksperimen menunjukkan perubahan dan perkembangan lebih baik dari hasil tulisan tahap pretest ke posttest. Kelas kontrol tidak banyak perkembangan dengan inti cerita yang sama namun pada hasil posttest menghasilkan fiksi ilmiah lebih lengkap dari hasil pretest.

\section{DAFTAR RUJUKAN}

Aqib, Z., \& M., dan A. (2016). Kumpulan Metode Pembelajaran Kreatif dan Inovatif. Bandung: PT Sarana Tutorial Nurani Sejahtera.

Aripin, U. dan, \& P., R. (2017). Penerapan Pembelajaran Berbasis Alternative Solutions Worksheet untuk Meningkatkan Kemampuan Berpikir Kreatif Matematik. AKSIOMA: Jurnal Program Studi Pendidikan Matematika, 6(2), $225-233$. https://doi.org/10.24127/ajpm.v6i2.989

Ayuni, R. D., Siswati, D., \& R., D. (2013). Pengaruh Storytelling Terhadap Perilaku Empati Anak. Psikologi Undip, 12(2), 81129. https://doi.org/10.14710/jpu.12.2.121-130

Bahri, H. (2019). Strategi Edutainment Berbasis Perkembangan Anak Usia Dini. Nuansa, 12(1), 30-43. https://doi.org/10.29300/nuansa.v12i1.2103

Hockstein, N. G., C. G. Gourin, R. A. Faust, dan D. J. T. (2007). A History of Robots : From Science Fiction to Surgical Robotics. Journal of Robotic Surgery, 1, 113-118. https://doi.org/10.1007/s11701-007-0021-2

Holis, A. (2006). Belajar Melalui Bermain untuk Pengembangan Kreativitas dan Kognitif Anak Usia Dini. Pendidikan Universitas Garut, 09(01), 23-37. https://doi.org/10.1142/9789812773678_0145

Inah, E. N. (2015). Peran Komunikasi dalam Interaksi Guru dan Siswa. Al-Ta'dib, 8(2), 150-167.

Kaye, J., \& D., P. (2014). Special Issue on Science Fiction and Ubiquitous Computing. Pers Ubiquit Comput, 18, $765-766$. https://doi.org/10.1007/s00779-014-0773-4

Kornienko, A. A., Anatoly V. K., Oleg B. F., M. P. C. (2015). Knowledge in Artificial Intelligence Systems: Searching the Strategies for Application. Sciendirect, 166, 589-594. https://doi.org/10.1016/j.sbspro.2014.12.578 
Kurnia, R. (2012). Konsepsi Bermain dalam Menumbuhkan Kreativitas pada Anak Usia Dini. EDUCHILD, 01(1), 77-85.

Leppink, J. (2017). Cognitive Load Theory: Practical Implications and an Important Challenge. Taibah University Medical Sciences, 12(5), 385-391. https://doi.org/10.1016/j.jtumed.2017.05.003

Lundquist, C. A. (2012). The Science and Fiction of Robert L . Forward. SciVerse ScienceDirect, 38, $109-115$. https://doi.org/10.1016/j.phpro.2012.08.016

Merrie, A., Patrick K., Marc M., H. O. (2018). Radical Ocean Futures-Scenario Development Using Science Fiction Prototyping. Futures, 95, 22-32. https://doi.org/10.1016/j.futures.2017.09.005

Nurmina. (2014). Menulis Kreatif Cerita Fiksi Anak. JUPENDAS, 1(2), 10-14.

Rahmah, N. (2014). PENDEKATAN DAN MODEL PEMBELAJARAN YANG MENGAKTIFKAN SISWA. AL-Khwarizmi, 2(1), 91-102.

Raven, P. G. (2017). Telling Tomorrows : Science Fiction as an Energy Futures Research Tool. Energy Research and Social Science, 31(October 2016), 164-169. https://doi.org/10.1016/j.erss.2017.05.034

Rosa, F. O. (2015). Analisis Kemampuan Siswa Kelas X pada Ranah Kognitif, Afektif, dan Psikomotorik. OMEGA: Jurnal Fisika dan Pendidikan Fisika, 1(2), 24-28.

Sabani, N. (2018). Generasi Milenial dan Absurditas Debat Kusir Virtual. INFORMASI: Kajian Ilmu Komunikasi, 48(1), 95108

Sayuti, S. A., Esti S. S., \& B. L. (2012). Resepsi Kesadaran Berbahasa secara Kritis dalam Aktivitas Penulisan Fiksi Guru dan Siswa. LITERA, 11(1), 15-33.

Suryadi, I. (2010). Teori Konvergensi Simbolik. JURNAL ACADEMICA Fisip Untad, 2(02), 426-437.

Triyanto. (2014). Pendidikan Seni Berbasis Budaya. Pendidikan Seni Berbasis Budaya, VIII(1), 33-42. 